\title{
Heavy Metals in the Environment
}

\section{Fate and Behavior of Lead in Soils Planted with Metal-Resistant Species (River Birch and Smallwing Sedge)}

\author{
Steve P. Klassen, Joan E. McLean,* Paul R. Grossl, and Ronald C. Sims
}

\begin{abstract}
Phytoremediation of metal-contaminated soils requires an understanding of the interactions between metal-tolerant plant species and soil chemical properties controlling the bioavailability of metals. We conducted controlled laboratory studies to investigate the effects that river birch (Betula occidentalis Hook.) and smallwing sedge (Carex microptera Mack.) had on the fate and behavior of $\mathrm{Pb}$ in a contaminated soil (3000 mg Pb/kg) and tailings (13 000 mg Pb/kg) collected from an abandoned mining site in Utah. Significant $\mathrm{Pb}$ accumulation in aboveground tissue was observed in smallwing sedge $(\geq 1000 \mathrm{mg} /$ kg dry wt.) in both the soil and tailings, but $\mathrm{Pb}$ was primarily excluded by birch ( $\leq 300 \mathrm{mg} / \mathrm{kg}$ dry wt.). Lead exclusion in birch resulted in elevated concentrations of $\mathrm{Pb}$ in the rooting zone in both the soil and tailings. In the soil, the exchangeable $\mathrm{Pb}$ concentration of the unplanted control was not significantly different than the birch rhizosphere but was higher than the birch bulk (nonrhizosphere) soil fraction. This suggested that plants using exclusionary mechanisms of metal resistance may promote soil $\mathrm{Pb}$ stabilization by sequestering normally mobile fractions of $\mathrm{Pb}$ in the rhizosphere. However, both birch and smallwing sedge increased the leachate $\mathrm{Pb}$ concentration by $2 \mathrm{mg} / \mathrm{L}$ and decreased the $\mathrm{pH}$ by one unit in the tailings compared with unplanted controls. Leachate $\mathrm{Pb}$ concentrations and $\mathrm{pH}$ were not significantly affected by plants in the soil. This indicated that the ability of metal-resistant plants to promote soil $\mathrm{Pb}$ stabilization is soil specific and depends on the level of $\mathrm{Pb}$ contamination and soil characteristics controlling the solubility and mobility of $\mathbf{P b}$.
\end{abstract}

$\mathrm{R}$ MEDIATION of metal-contaminated soils using plants that accumulate heavy metals is currently being studied throughout the world (Wu et al., 1999; Cunningham et al., 1995; Schnoor et al., 1995). This remediation strategy, termed phytoremediation, may provide a more economical and aesthetically pleasing alternative to conventional remediation options. The phytoremediation of $\mathrm{Pb}$-contaminated soils is particularly challenging due to the low mobility and generally low bioavailability of this widespread contaminant in soils (Kumar et al., 1995; Huang and Cunningham, 1996). In addition, few species worldwide have been found that accumulate high levels of $\mathrm{Pb}(\geq 1000 \mathrm{mg} / \mathrm{kg}$ dry wt.) in aboveground tissues (Baker and Brooks, 1989).

Most plants are highly sensitive to heavy metals and

Steve P. Klassen, Dep. of Plants, Soils, and Biometeorology, Utah State Univ., Logan, UT 84322-4820; Joan E. McLean, Utah Water Research Lab., Dep. of Civil and Environmental Engineering, Utah State Univ., Logan, UT 84322-8200; Paul R. Grossl, Dep. of Plants, Soils, and Biometeorology, Utah State Univ., Logan, UT 84322-4820; Ronald C. Sims, Utah Water Research Lab., Dep. of Civil and Environmental Engineering, Utah State Univ., Logan, UT 84322-8200. Received 1 Sept. 1999. *Corresponding author (jmcle@cc.usu.edu).

Published in J. Environ. Qual. 29:1826-1834 (2000). cannot endure even low concentrations in soils (Larcher, 1980), but environments with high concentrations of heavy metals can be colonized by plants that are metal resistant (Shaw, 1990). Metal resistance can be achieved through a variety of mechanisms that can be defined as either mechanisms of avoidance or tolerance. Levitt (1980) defines avoidance as the ability to prevent excessive metal uptake, and tolerance as the ability to cope with metals that are excessively accumulated in some part of the plant. Plants that use mechanisms of avoidance are often referred to as metal excluders, and metal tolerant plants as metal accumulators.

The initial emphasis in phytoremediation research has been on a small number of wild plants termed hyperaccumulators that are able to accumulate high concentrations of specific metals in aboveground tissues (Baker et al., 1988, 1994; Chaney et al., 1995). Many of these species are slow growing, produce low biomass, and have very specific growing requirements, making them less suitable for use in phytoremediation. Therefore, current efforts have emphasized using agricultural species, such as Brassica spp., Zea mays L., and Nicotiana spp., that could be grown efficiently following established agricultural practices (Wu et al., 1999; Huang and Cunningham, 1996; Kumar et al., 1995; Mench and Martin, 1991). This research is promising since a variety of species have been identified that can accumulate high concentrations of certain metals. Such species generally require significant maintenance in the form of irrigation, fertilization, and use of herbicides, insecticides, and other soil amendments. Thus the use of these species is restricted to arable lands and would not be applicable to more highly disturbed and remote areas such as abandoned mine sites.

Our efforts to develop phytoremediation have focused on identifying native plant species adapted to growing conditions in the U.S. Intermountain West that can accumulate high concentrations of $\mathrm{Pb}$. Such species are not only adapted to the local environment, but also have demonstrated the ability to tolerate highly disturbed conditions typical of abandoned mine sites. Some of these plants may affect significantly the movement and fate of $\mathrm{Pb}$ in soil, promoting both soil decontamination and stabilization. The identification and characterization of metal resistance in these plants could prove valuable in developing phytoremediation strategies for mine sites and other areas of $\mathrm{Pb}$ contamination in the Intermountain West.

Lead accumulation in the aboveground plant tissues sampled from an abandoned mine site in Utah was studied by Klassen (1998). Mean Pb concentrations in young 
woody stems of river birch, and in the shoots of a common sedge, smallwing sedge, were 887 and $485 \mathrm{mg} / \mathrm{kg}$, respectively. This paper describes a controlled laboratory study examining aspects of $\mathrm{Pb}$ resistance and accumulation in the two identified species, birch and smallwing sedge. Use of the two species selected provides a good comparison of two plants that are very different in regard to growth, morphology, and life history.

The purpose of this study was to characterize how mechanisms of $\mathrm{Pb}$ resistance and plant-soil interactions affect $\mathrm{Pb}$ accumulation and soil $\mathrm{Pb}$ stabilization by the two plant species. The experiment was designed to: (i) evaluate plant uptake of $\mathrm{Pb}$, survival, and biomass production in three soils that differ in metal content, $\mathrm{pH}$, and nutrient content; (ii) determine the effects of plants on leachate solution $\mathrm{pH}$ and $\mathrm{Pb}$ content; and (iii) determine the effects of plants on soil $\mathrm{Pb}$.

\section{MATERIALS AND METHODS}

A completely randomized block design was implemented with three plant treatments and three soil treatments. Each treatment combination was replicated three times resulting in nine planted pots for each plant species, and nine unplanted pots for a total of 27 pots.

Measured variables included: (i) $\mathrm{Pb}$ concentrations and $\mathrm{pH}$ of leachates, (ii) measurements of water loss, (iii) end-of-study plant $\mathrm{Pb}$ concentrations, (iv) initial and end-of-study total $\mathrm{Pb}$ concentrations in bulk and rhizosphere soil, (v) initial and end-of-study exchangeable $\mathrm{Pb}$ concentrations in bulk and rhizosphere soil, (vi) final dry weight of plant tissues, and (vii) plant survival. Geochemical modeling (GEOCHEM-PC) and $\mathrm{X}$-ray diffraction techniques were used to identify the primary mineral phases controlling $\mathrm{Pb}$ solubility in the contaminated soil and tailings (Parker et al., 1995).

\section{Plant and Soil Treatment Design}

Pots were $46 \mathrm{~cm}$ tall, constructed from 15.24-cm-i.d. (6 in) PVC pipe. A port was installed at the base of each pot to allow for adequate drainage and collection of leachate samples. Pots were maintained in a laboratory at $20^{\circ} \mathrm{C}$ under artificial lighting (16-h days, 1000-W high pressure sodium ballast) for a period of 4 mo.

Soil (unclassified) and tailings collected from the Pacific Mine were used for the two contaminated soil samples. The Pacific Mine is located in the American Fork Canyon Mining District, approximately $32 \mathrm{~km}$ north-northeast of Provo, UT. Kidman sandy loam (coarse-loamy, mixed, Mesic Calcic Haploxeroll) was used as a control soil. The three soil samples are representative of the broad range of contaminant levels, soil $\mathrm{pH}$, and fertility associated with abandoned mine sites (Table 1). Soils were air-dried and passed through a 5-mm screen to remove rocks and ensure uniformity. Soils were mixed thoroughly prior to addition to pots and were packed at uniform bulk densities, based on textural classes, of 1.45 , 1.25 , and $1.65 \mathrm{~kg} / \mathrm{L}$ in the Kidman, site, and tailings treatments, respectively.

Three plant treatments were used: (i) birch seedlings, (ii) smallwing sedge seedlings, and (iii) unplanted as a control. Birch and smallwing sedge seedlings were germinated from seed collected at the Pacific Mine. Birch seedlings were grown indoors for a period of 9 mo prior to being transplanted into the soil treatments. Birch seedlings had an average height of $51 \mathrm{~cm}$ and basal diameter of $2 \mathrm{~cm}$. Smallwing sedge seedlings
Table 1. Treatment of soil properties.

\begin{tabular}{|c|c|c|c|}
\hline Soil & Kidman & Site & Tailings \\
\hline Total Pb, mg/kg & $<\mathbf{1 0}$ & 3023 & 12914 \\
\hline Total Cd, mg/kg & $<\mathbf{2 . 0}$ & $<\mathbf{2 . 0}$ & 8 \\
\hline Total $\mathrm{Zn}, \mathrm{mg} / \mathrm{kg}$ & 35 & 409 & 2028 \\
\hline Total Cu, mg/kg & 6 & 112 & 147 \\
\hline Total Ni, mg/kg & 9 & 12 & $<8$ \\
\hline Total S, g/kg & 0.1 & 1.1 & 3.8 \\
\hline Soluble S, mg/L & 25.3 & 228 & 103 \\
\hline pH & 7.9 & 3.7 & 3.6 \\
\hline Clay, g/kg & 120 & 130 & 110 \\
\hline Silt, g/kg & 190 & 400 & 180 \\
\hline Organic carbon, g/kg & 10.3 & 29.0 & 6.8 \\
\hline $\mathrm{CEC}_{\dagger} \dagger, \mathrm{cmol} / \mathrm{kg}$ & 7.8 & 24.1 & 4.2 \\
\hline $\mathrm{NO}_{3}-\mathrm{N}, \mathrm{mg} / \mathrm{kg}$ & 65.4 & 16.9 & $<\mathbf{5 . 0}$ \\
\hline Available $\mathbf{P}, \mathrm{mg} / \mathrm{kg}$ & 24.0 & 26.0 & 5.1 \\
\hline Available $\mathbf{K}, \mathbf{m g} / \mathbf{k g}$ & 296 & $\mathbf{5 3}$ & 37 \\
\hline Texture & sandy loam & loam & sandy loam \\
\hline
\end{tabular}

$\dagger$ Cation exchange capacity.

were grown indoors for 3 mo prior to transplantation to soil treatments. Smallwing sedge seedlings had an average height of $19 \mathrm{~cm}$.

Pots were initially watered in excess and allowed to drain for a period of $24 \mathrm{~h}$. Pots were then weighed and the field capacity for each treatment determined by the mass of water retained by the pots. The average field capacity for each treatment was approximately 38,40 , and $31 \%$ (v/v) in the Kidman, site, and tailings treatments, respectively. Thereafter, pots were watered weekly. The volume of water added each week was determined by the change in weight of each pot between watering plus $10 \%$ to ensure drainage. The initial watering included the addition of $1 \mathrm{~L}$ of $0.013 M \mathrm{KNO}_{3}$ to each pot in order to alleviate transplant shock. This resulted in a fertilization rate equivalent to $100 \mathrm{~kg} / \mathrm{ha} \mathrm{N}$.

\section{Sampling Methods}

Leachate samples were collected over a 24 - to 48 -h period following each watering event. The volumes of water added and water drained were recorded to account for water losses. Plants were harvested $4 \mathrm{mo}$ after planting. Aboveground tissues of the birch were separated into the following fractions: leaves, small-diameter stems $(<3 \mathrm{~mm})$, and large-diameter stems $(>3 \mathrm{~mm})$. Senescent stems and leaves also were separated from each of the aboveground tissue fractions. Analysis results for these tissue fractions were combined to determine average aboveground values for the birch treatments. Aboveground tissues of the smallwing sedge were collected as a single sample. Plant roots were carefully removed from the soil and shaken to collect rhizosphere soil. Rhizosphere soil was defined as soil loosely associated with the roots as described by Marschner (1995). The rhizosphere sample collected constituted approximately 1 to $2 \%$ of the total mass of soil within a pot. The remaining soil fraction was classified as bulk soil. Roots and soils also were separated into the following three fractions based on depth: top $(0-12.7 \mathrm{~cm})$, middle $(12.7-25.4 \mathrm{~cm})$, and bottom $(25.4-38.1 \mathrm{~cm})$. Analysis results for samples separated by depth were combined to determine average values for each treatment.

\section{Methods of Analysis}

Following $\mathrm{pH}$ measurements, leachate samples were preserved with nitric acid $(\mathrm{pH}<2)$ and stored at $4^{\circ} \mathrm{C}$ for metals analysis. Plant tissues were washed using $30-\mathrm{s}$ washings in $0.3 \%$ sodium lauryl sulfate, $1 \mathrm{mM} \mathrm{HCl}$, and deionized water. This washing procedure was determined to be effective at removing surface contamination based on the analysis of $\mathrm{Ti}$ 
and $\mathrm{Cr}$ of plant samples collected in the field (Klassen, 1998). Tissues were dried for $24 \mathrm{~h}$ at $103^{\circ} \mathrm{C}$ and weighed to determine a final dry biomass. We realized this drying temperature was higher than the recommended temperature of $80^{\circ} \mathrm{C}$ and may have resulted in up to a $10 \%$ underestimate of the actual biomass (Jones and Case, 1990). Although such a loss would increase the experimental error of the data, we feel it would not significantly affect the conclusions drawn. Dried tissues were finely ground and digested in nitric acid following standard procedures (Jones and Case, 1990). Soils were air-dried and sieved to 20 mesh to ensure uniformity. Samples for total metal analysis were digested in nitric acid and hydrogen peroxide following standard procedures (Method 3050; USEPA, 1992). Samples for exchangeable $\mathrm{Pb}$ analysis were extracted in $1 \mathrm{M} \mathrm{CaCl}_{2}$ for a period of $1 \mathrm{~h}$ following a modified version of the procedure described by Tessier et al. (1979). Tessier's procedure used $1 \mathrm{M} \mathrm{MgCl}_{2}$.

The $\mathrm{Pb}$ content of all leachate samples was determined using inductively coupled argon plasma emission spectrometry (ICP) (PerkinElmer [Norwalk, CT] Model 6000). The Pb content of all plant and soil samples was analyzed using flame atomic absorption spectrophotometry (FAA) (PerkinElmer Model 5000). Leachate $\mathrm{pH}$ was determined using a $\mathrm{pH}$ electrode and soil $\mathrm{pH}$ was determined by the saturation paste method (Richards, 1954). Initial soil properties were analyzed by the Utah State University Soils Testing Laboratory for the following: total elemental analysis by nitric-perchloric digestion (Barnhisel and Bertsch, 1982), water soluble elements by saturated paste (Rhoades, 1982), cation exchange capacity by a $1 M$ ammonium acetate extraction (Richards, 1954), nitrate nitrogen by a $2 M$ potassium chloride extraction (Keeney and Nelson, 1982), available $\mathrm{P}$ and $\mathrm{K}$ by a sodium bicarbonate extraction (Olsen and Sommers, 1982), organic carbon content by the Walkley and Black method (Nelson and Sommers, 1982), and particle analysis by the hydrometer method (Gee and Bauder, 1986).

\section{Statistical Analysis}

Significance testing of time-dependent repeated-measures data was conducted with a SAS system using a Proc Mixed procedure for analysis of variance (SAS Institute, 1996). For simplicity, the repeated-measures analysis was limited to fixed effects between treatments since this provides the clearest comparisons. Time is factored out, and only the mean data values are presented. All end-of-study measurements were analyzed with StatView 4.01 using a general linear model for analysis of variance (Abacus Concepts, 1993). Since no obvious trends were apparent in a statistical analysis of samples separated by depth, soil and root data collected from the three depths within a pot were combined into a single average for the pot. Birch aboveground tissue data were combined into a single aboveground fraction in order to facilitate comparisons with smallwing sedge.

\section{RESULTS AND DISCUSSION}

\section{Soil Water}

The ability of plants to alter the $\mathrm{pH}$ of rhizosphere soils is well documented and can be attributed to the excretion or absorption of $\mathrm{H}^{+}$or $\mathrm{HCO}_{3}^{-}, \mathrm{CO}_{2}$ evolution by root respiration, the release of organic and amino acids (root exudates), and enhanced rhizosphere oxygenation (Dunbabin et al., 1988; Marschner and Romheld, 1996). As a result, rhizosphere and bulk soils may differ in $\mathrm{pH}$ by two or more units (Marschner and Rom-
Table 2. Treatment effects on mean leachate $\mathrm{pH}$ and mean total $\mathrm{Pb}$ concentrations.

\begin{tabular}{|c|c|c|c|}
\hline Soil & Plant & Mean pH & Mean Pb \\
\hline $\begin{array}{l}\text { Control } \\
\text { Control } \\
\text { Control }\end{array}$ & $\begin{array}{l}\text { unplanted } \\
\text { birch } \\
\text { smallwing sedge }\end{array}$ & $\begin{array}{l}8.4 \mathrm{a} \dagger \\
8.2 \mathrm{~b} \\
8.0 \mathrm{c}\end{array}$ & $\mathrm{mg} / \mathrm{L}$ \\
\hline $\begin{array}{l}\text { Site } \\
\text { Site } \\
\text { Site }\end{array}$ & $\begin{array}{l}\text { unplanted } \\
\text { birch } \\
\text { smallwing sedge }\end{array}$ & $\begin{array}{l}\text { 4.6ab } \\
4.6 \mathrm{~b} \\
4.7 \mathrm{a}\end{array}$ & $\begin{array}{l}2.2 \mathrm{a} \\
2.2 \mathrm{a} \\
1.9 \mathrm{a}\end{array}$ \\
\hline $\begin{array}{l}\text { Tailings } \\
\text { Tailings } \\
\text { Tailings }\end{array}$ & $\begin{array}{l}\text { unplanted } \\
\text { birch } \\
\text { smallwing sedge }\end{array}$ & $\begin{array}{l}6.0 \mathrm{a} \\
4.8 \mathrm{c} \\
5.1 \mathrm{~b}\end{array}$ & $\begin{array}{l}2.6 b \\
4.5 a \\
4.1 a\end{array}$ \\
\hline
\end{tabular}

$\dagger$ Means within a soil treatment with the same letter are not significantly different (Fisher's PLSD, $p<0.05$ ).

held, 1996). Whether such differences can affect the $\mathrm{pH}$ of soil water leaching from planted systems has not been well documented.

The results of the leachate analysis show some significant differences between plant treatments in all three soils (Table 2). Although the differences in $\mathrm{pH}$ between plant treatments in the control and site soils were small $(<0.5 \mathrm{pH}$ units), prominent plant effects were seen in the tailings treatment, with a decrease in mean $\mathrm{pH}$ by approximately one unit in both birch and smallwing sedge. Differences in the buffering capacity of the soils (control and site) and tailings, and in the rates of root exudation, were probably responsible for the degree of pH changes seen (Marschner and Romheld, 1996). The greater buffering capacity of the soils is indicated by the higher CEC, organic matter content, and clay content than in the tailings (Table 1). Thus, the soils resisted changes in $\mathrm{pH}$ to a greater extent than the tailings.

Plants may have increased acid production in the tailings by promoting mechanisms that influence the rate of metal sulfide oxidation. Metal sulfides are commonly found in hard rock mining wastes (Amacher et al., 1993). Plants physically alter the soil environment by penetrating the soil profile with roots and actively removing water, thus promoting processes of oxidation (Anderson et al., 1993). Plants also may have promoted the growth and activity of soil microorganisms that catalyze the oxidation of metal sulfides. Studies on metal sulfide oxidation in the rhizosphere of metal-resistant plants are needed to better understand such plant-soil interactions.

As with $\mathrm{pH}$, the $\mathrm{Pb}$ concentrations of leachates from the planted and unplanted treatments in the site soil were not significantly different (Table 2). However, in the tailings the $\mathrm{Pb}$ concentrations of leachates from planted treatments were significantly higher than from unplanted treatments (Table 2). The increased leachability of $\mathrm{Pb}$ observed in the planted tailings is consistent with several other findings documented in the literature on the effects of vegetation on heavy metal leachates (Banks et al., 1994a,b).

Root exudates may affect both metal solubility (i.e., via complexation) and soil $\mathrm{pH}$. Ideally, we would have measured root exudation. However, the quantitative measurement of root exudates in soil is problematic due to the rapid microbial degradation of such compounds 


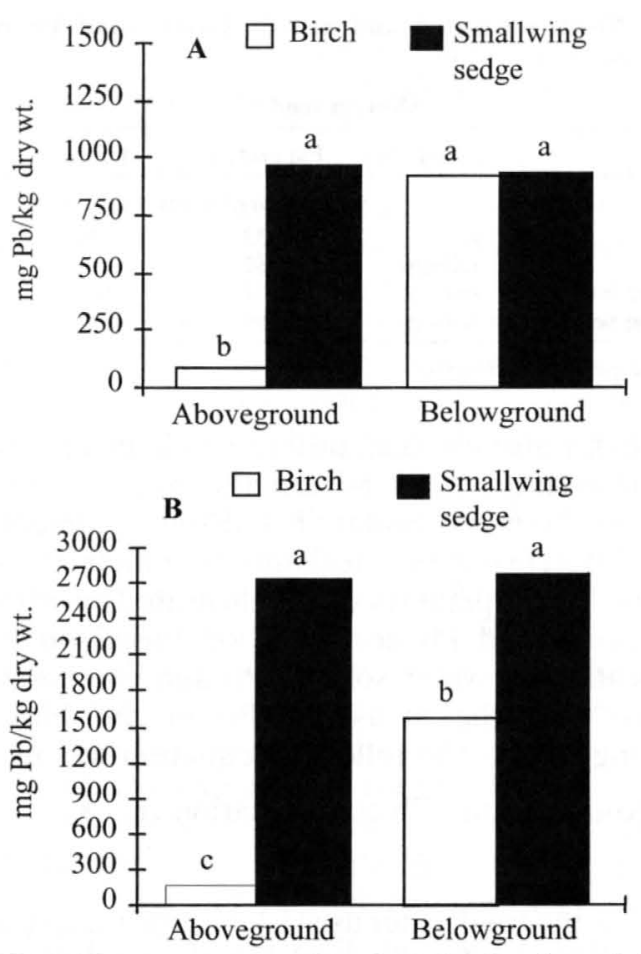

Fig. 1. Mean $\mathrm{Pb}$ concentrations for plants in the site soil $(A)$ and tailings $(B)$ treatment (bars with different letters are significantly different, DF $=11, p \leq 0.05)$.

(Burken and Schnoor, 1996). The inherent solubility of native organic matter and microbial exudation further complicates the measurement of root exudation in soils.

\section{Plants}

Preliminary field studies indicated that these plants were unusually tolerant of such contaminated soils (Klassen, 1998). The end-of-study survival rate of $100 \%$ in all treatments demonstrated the unique ability of both plant species to grow in metal-contaminated soils. Undoubtedly, the plants experienced some degree of stress growing in the metal-contaminated soil and tailings. There were, however, no visible signs of nutrient deficiency or toxicity symptoms during plant growth, except for the reduced size of the smallwing sedge growing in the tailings treatment. We made no attempt to optimize the productivity of the plants with soil amendments since this would affect the behavior of $\mathrm{Pb}$ in the soils.

The metal accumulation results indicated that there are differences in the mechanisms of metal resistance between the two plant species (Fig. 1a,b). In both site and tailings treatments, smallwing sedge aboveground and belowground $\mathrm{Pb}$ concentrations were not significantly different, suggesting passive translocation of $\mathrm{Pb}$ from root to shoot. In contrast, $\mathrm{Pb}$ translocation was inhibited in the birch, resulting in significantly lower $\mathrm{Pb}$ concentrations in the shoots in both site and tailings treatments. As expected, tissues of plants growing in the tailings had higher $\mathrm{Pb}$ concentrations than respective tissues of plants growing in the site soil.

Birch aboveground and belowground biomass was
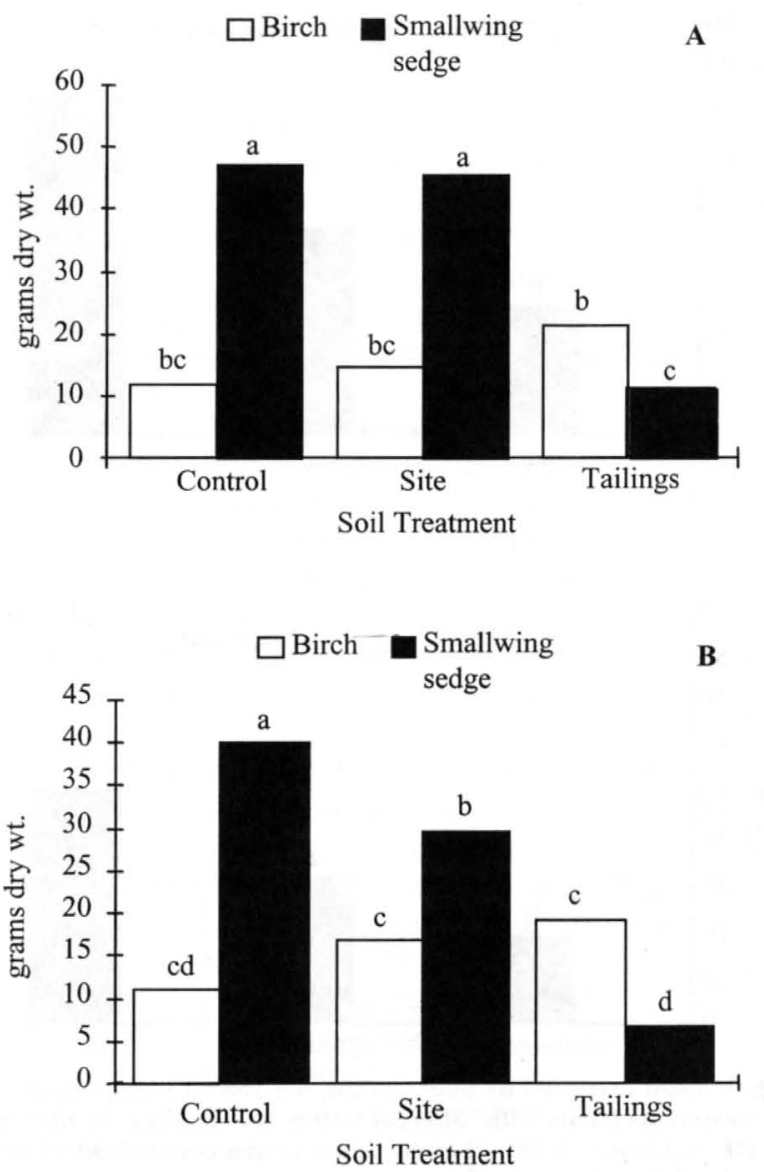

Fig. 2. Mean aboveground $(A)$ and belowground $(B)$ weights (bars with different letters are significantly different, $\mathrm{DF}=17, p \leq 0.05$ ).

not significantly different among soil treatments (Fig. 2a,b). Smallwing sedge shoot production was not inhibited in the site soil but was markedly reduced in the tailings (Fig. 2a,b). Smallwing sedge root production was not only reduced in the tailings but also to a lesser extent in the site soil. As a result, the root-to-shoot ratios remained relatively constant in the birch while the smallwing sedge root-to-shoot ratios declined in response to increasing soil treatment $\mathrm{Pb}$ concentrations. This suggested that birch were more resistant to $\mathrm{Pb}$ contaminated soils than smallwing sedge.

Often metal accumulation data are presented only in terms of concentration in the plant and not in terms of the mass of metal removed from the soil. Since metal removal is a potential goal of phytoremediation, the data are presented also as mass of $\mathrm{Pb}$ extracted. Approximately $90 \%$ of the $\mathrm{Pb}$ accumulated by the birch was in the roots in both $\mathrm{Pb}$ treatments (Fig. 3a,b). Thus the birch was able to protect its photosynthetic processes from $\mathrm{Pb}$ toxicity by sequestering $\mathrm{Pb}$ in the roots and possibly excluding $\mathrm{Pb}$ at the soil-root interface. The potential advantage $\mathrm{Pb}$ exclusion affords to plant growth has previously been documented in a study on the $\mathrm{Pb}$ tolerance of legume species grown on $\mathrm{Pb}$ ore tailings (Sudhakar et al., 1992). In contrast, approximately $60 \%$ of the $\mathrm{Pb}$ extracted by the smallwing sedge was in the shoots in both the site soil and tailings. Significant $\mathrm{Pb}$ 

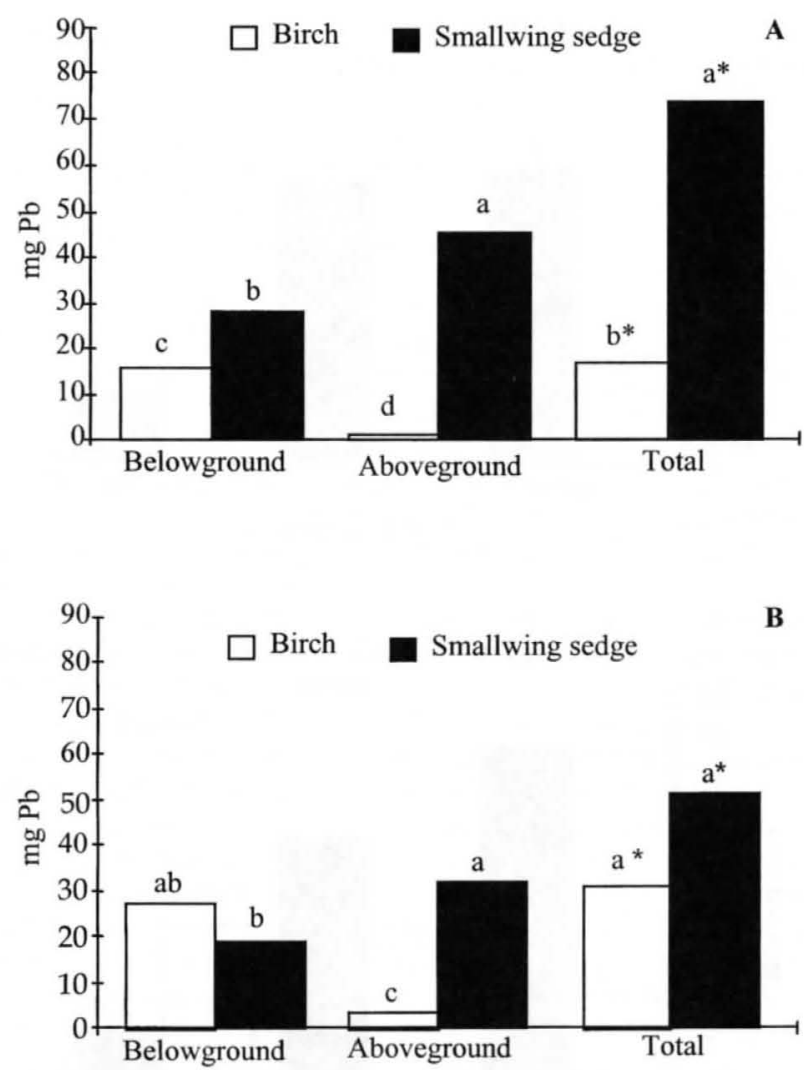

Fig. 3. Lead extracted by plants in the site soil $(A)$ and tailings $(B)$ treatments [(bars with different letters are significantly different, $\mathrm{DF}=11, p \leq 0.05)$. *Letters apply to the comparison of totals only $(\mathrm{DF}=\mathbf{5}, p \leq 0.05)]$.

accumulation, combined with excellent growth on the site soil and survival in the tailings, demonstrated that the smallwing sedge is $\mathrm{Pb}$ tolerant. Limitations to this tolerance of $\mathrm{Pb}$ accumulation in the aboveground tissues were probably the cause for the inhibition in growth seen in the smallwing sedge. Despite these limitations, the smallwing sedge extracted approximately four times more $\mathrm{Pb}$ in the site soil than the birch on a total basis (Fig. 3a). The total $\mathrm{Pb}$ extracted in the tailings was not significantly different between the two species (Fig. 3b). Neither plant species, however, removed significant levels of $\mathrm{Pb}$ from these highly contaminated test soils. Although smallwing sedge would be classified as a $\mathrm{Pb}$ hyperaccumulating plant $(>1000 \mathrm{mg} \mathrm{Pb} / \mathrm{kg})$, the total amount of $\mathrm{Pb}$ removed from the soils via plant uptake (Fig. 3a,b) and leaching ( $<10 \mathrm{mg} \mathrm{Pb})$ was insignificant compared with the total mass of $\mathrm{Pb}$ in the soils (30 $000 \mathrm{mg} \mathrm{Pb}$ in the site soil and $130000 \mathrm{mg} \mathrm{Pb}$ in the tailings).

It is important to evaluate differences in the rates of water use between species since transpiration is the driving force controlling the flux of soluble heavy metals to the plant. In the site soil, the birch used much less water $(0.71 \mathrm{~L} / w \mathrm{wk})$ than the smallwing sedge $(1.57 \mathrm{~L} /$ wk), thus the birch had a lower flux of soluble heavy metals to the plant. However, in the tailings the birch water use was significantly higher $(0.94 \mathrm{~L} / \mathrm{wk})$ than the smallwing sedge $(0.53 \mathrm{~L} / \mathrm{wk})$. This indicated that factors
Table 3. Mean estimated and actual aboveground $\mathbf{P b}$ concentrations.

\begin{tabular}{llccc}
\hline \multicolumn{5}{c}{ Aboveground Pb } \\
\hline Plant & Soil & Estimated & Actual & RPD $\dagger$ \\
\hline & & mg/kg dry & wt. & \\
Birch & site & $\mathbf{1 0 3 3}$ & $\mathbf{9 6}$ & $\mathbf{8 3}$ \\
Birch & tailings & $\mathbf{1 8 5 2}$ & $\mathbf{2 0 2}$ & $\mathbf{8 0}$ \\
Smallwing sedge & site & $\mathbf{7 8 2}$ & $\mathbf{9 8 6}$ & $\mathbf{1 2}$ \\
Smallwing sedge & tailings & $\mathbf{2 1 9 9}$ & $\mathbf{2 7 5 1}$ & $\mathbf{1 1}$ \\
\hline
\end{tabular}

$\dagger$ Relative percent difference.

other than water use (i.e., differences in mechanisms of metal resistance) must govern the response of these species to the metal-contaminated soil treatments.

This difference in the mechanisms of metal resistance between the two plant species is illustrated by estimating the aboveground $\mathrm{Pb}$ accumulation based on passive translocation of water soluble $\mathrm{Pb}$ and comparing this estimate with the measured $\mathrm{Pb}$ in the birch and smallwing sedge. The following equation was used:

Aboveground $\mathrm{Pb}$ concentration $(\mathrm{mg} / \mathrm{kg})=$

$$
E \times L / Y
$$

where $E$ is the total water use (L), $L$ is the mean leachate $\mathrm{Pb}$ concentration $(\mathrm{mg} / \mathrm{L})$, and $Y$ is the total dry weight of roots and shoots $(\mathrm{kg})$. This equation is based on the following simplifying assumptions: (i) water-soluble $\mathrm{Pb}$ is passively translocated from soil to plant, (ii) accumulated $\mathrm{Pb}$ is evenly distributed between aboveground and belowground tissues, (iii) evaporation is insignificant, and (iv) mean leachate $\mathrm{Pb}$ concentrations are representative of soluble $\mathrm{Pb}$ concentrations at the soil-root interface. Despite the simplicity of this equation, estimates for smallwing sedge in both $\mathrm{Pb}$ treatments are reasonably close to the observed results (Table 3 ). This suggests that soluble $\mathrm{Pb}$ associated with the flux of water into the roots of smallwing sedge is taken up by the plant. In contrast, the birch primarily excludes this $\mathrm{Pb}$ from aboveground tissues and must rely on storage in the roots and possibly exclusion at the soil-root interface.

Surprisingly, smallwing sedge grown in the laboratory study accumulated higher concentrations of $\mathrm{Pb}(>1000$ $\mathrm{mg} / \mathrm{kg}$ dry wt.) than plants growing at the Pacific Mine site with average aboveground $\mathrm{Pb}$ concentrations of 485 $\mathrm{mg} / \mathrm{kg}$ dry wt. (Klassen, 1998). This may be attributed to the more ideal growing conditions of the laboratory and the homogeneity of the soil treatments. However, analysis of birch stem tissues collected from the Pacific Mine site (average $\mathrm{Pb}$ concentration of $887 \mathrm{mg} / \mathrm{kg}$ dry wt.) suggested birch is capable of accumulating much higher concentrations of $\mathrm{Pb}$ than demonstrated in the laboratory study ( $<300 \mathrm{~g} / \mathrm{kg}$ dry wt.) (Klassen, 1998). The results of a $\mathrm{Ti}$ analysis were below detection limits $(1 \mathrm{mg} / \mathrm{kg})$ for all tissues sampled in the field, suggesting that $\mathrm{Pb}$ accumulation in the mine site plants was not due to surface contamination. Results from a hydroponic study also demonstrated the ability of birch to translocate concentrations of $\mathrm{Pb}$ in excess of $1000 \mathrm{mg} /$ kg dry wt. (Klassen, 1998). A review of the literature 
on the mobility of $\mathrm{Pb}$ in woody plant species provides two probable explanations for this discrepancy.

Even if aboveground tissues of plants collected in the field are adequately washed, $\mathrm{Pb}$ within the tissues may have been derived from surface deposits (Lepp and Dollard, 1974). Lepp and Dollard (1974) investigated the lateral transport of bark-applied $\mathrm{Pb}$ from bark to wood in six deciduous trees. Under the experimental conditions of this study, they reported that approximately $30 \%$ of the bark-applied $\mathrm{Pb}$ was transported to wood in all six species. This suggests that a significant proportion of $\mathrm{Pb}$ accumulated in the woody stems of trees growing in areas with heavy metal contamination is derived from atmospheric sources. It is plausible that birch trees growing at the Pacific Mine site intercept high concentrations of airborne $\mathrm{Pb}$. The site not only experiences strong mountain winds but also is frequently visited by motorists on all-terrain vehicles that create dust as they traverse the tailing dumps.

An alternative explanation for this discrepancy is the potential for woody species to translocate $\mathrm{Pb}$ that has been temporarily stored in the roots during previous years of exposure. The remobilization of $\mathrm{Pb}$ stored in plants during a previous year has been documented in red spruce (Picea rubens Sarg.) seedlings (Donnelly et al., 1990). Such a mechanism could provide a plant with the ability to purge the roots of previously stored $\mathrm{Pb}$, concentrating it in older xylem tissues that will soon become nonconducting wood. Thus a species that excludes $\mathrm{Pb}$ in its first year of exposure may accumulate $\mathrm{Pb}$ during successive years. Longer-term studies are required to fully understand the mechanisms of $\mathrm{Pb}$ resistance in long-lived woody species such as birch.

\section{Soils}

In order to elucidate changes in the $\mathrm{Pb}$ chemistry of the soil associated with plant processes, $\mathrm{C} \mathrm{CaCl}_{2}$ extraction was used in addition to the analysis of total soil $\mathrm{Pb}$. The $\mathrm{Pb}$ extracted with $\mathrm{CaCl}_{2}$ is operationally defined as the exchangeable fraction of $\mathrm{Pb}$ in soil. This fraction is considered to be the more mobile fraction of $\mathrm{Pb}$ in equilibrium with the aqueous fraction of soil (McLean and Bledsoe, 1992). Thus, this extraction provides information on both changes in the relative mobility and potential bioavailability of $\mathrm{Pb}$ in the soils. Considering the relatively slow uptake rate of $\mathrm{Pb}$ by the plants, significant changes in the metal concentrations of planted soil treatments were not expected. Despite the short duration $(4 \mathrm{mo})$ of this study, some significant differences were found between the rooting zone and bulk soil $\mathrm{Pb}$ concentrations of planted treatments (Fig. $4 \mathrm{a}, \mathrm{b}$ ). There were no significant differences between initial and end-of-study $\mathrm{Pb}$ concentrations of unplanted soils (Table 1, Fig. 4a,b), indicating that observed changes in soil $\mathrm{Pb}$ concentrations in the planted systems were not an artifact of the experimental procedure.

In the site soil, the total $\mathrm{Pb}$ concentration for the birch bulk soil was the same as for the control, whereas the total $\mathrm{Pb}$ concentration in the rooting zone soil increased relative to the control and bulk soil (Fig. 4a).
The extractable $\mathrm{Pb}$ concentration of the birch bulk soil was, however, lower than the control. This suggested that the labile fraction of $\mathrm{Pb}$ in the bulk soil was transported to the rhizosphere soil. Despite the increase in total $\mathrm{Pb}$ in the birch rooting zone soil, the extractable $\mathrm{Pb}$ concentration was not significantly different than the unplanted control. This result suggests that the mobility of $\mathrm{Pb}$ decreased upon entering the rhizosphere, further supporting an exclusionary mechanism of metal resistance in this species.

Although smallwing sedge rooting zone soil was not depleted in total $\mathrm{Pb}$, the lack of enrichment, as observed for the birch rhizosphere soil, agrees with a mechanism based on passive accumulation (Fig. 4a). The extractable $\mathrm{Pb}$ concentrations of the smallwing sedge rooting zone and bulk fraction were both lower than the control. This is consistent with a mechanism of $\mathrm{Pb}$ accumulation in which the plant removes the more labile $\mathrm{Pb}$ from the soil.

As was observed with the site soil, the total $\mathrm{Pb}$ concentration in the birch rooting zone of the tailings was significantly enriched over the unplanted control (Fig. 4b). But unlike the site rhizosphere soil, there was an observed increase in the exchangeable concentration of $\mathrm{Pb}$ in this rhizosphere soil. All other soils had the same total $\mathrm{Pb}$ concentration as the control but also had significantly higher concentrations of extractable $\mathrm{Pb}$ than the control. This was consistent with the increased leaching of $\mathrm{Pb}$ in the planted tailings treatment (Table 2).

In order to understand the processes within the planted and unplanted soils that are contributing to the immobilization-mobilization of $\mathrm{Pb}$, we need to identify the primary solid phase controlling the solubility of $\mathrm{Pb}$ in these soils. The tailings were derived from a mineralized zone high in primary sulfides, secondary sulfates, and hydrous sulfates (Lidstone and Anderson, 1993). X-ray diffraction analysis of the initial site soil and tailings suggested the presence of mixed oxides of $\mathrm{Pb}$ and sulfate. A saturation paste extract of the unplanted and rooting zone site soil and tailings was analyzed for $\mathrm{Ca}$, $\mathrm{Mg}, \mathrm{Na}, \mathrm{K}, \mathrm{Al}, \mathrm{Fe}, \mathrm{Mn}, \mathrm{Zn}, \mathrm{Pb}, \mathrm{Cd}$, sulfate, phosphate, chloride, silicate, nitrate, electrical conductivity, and $\mathrm{pH}$. Due to limited quantities of the rooting zone soils, replicate samples were combined, eliminating expression of experimental error and statistical comparison of treatment effects, but allowing prediction of solid phase chemistry. GEOCHEM-PC, a chemical speciation modeling program, was used to calculate the free ion activities of $\mathrm{Pb}$ and various anions in the saturation paste extract and to predict which solid phases might be controlling aqueous $\mathrm{Pb}$ levels (Parker et al., 1995). The results were compared with predicted solution activities as controlled by different solid phases following the assumptions described by Lindsay (1979). Solution $\mathrm{Pb}$ activities suggest that $\mathrm{PbSO}_{4}$ and $\mathrm{Pb}_{5}\left(\mathrm{PO}_{4}\right)_{3} \mathrm{Cl}$ (pyromorphite) are probably the primary solid phases controlling $\mathrm{Pb}$ activity in solution under the acidic conditions of the tailings and site soil with and without plants (Fig. 5).

Recent studies have shown the potential for decreased $\mathrm{Pb}$ solubility in the rhizosphere due to the precipitation of $\mathrm{Pb}$ phosphates (Traina and LaPerche, 1999; 

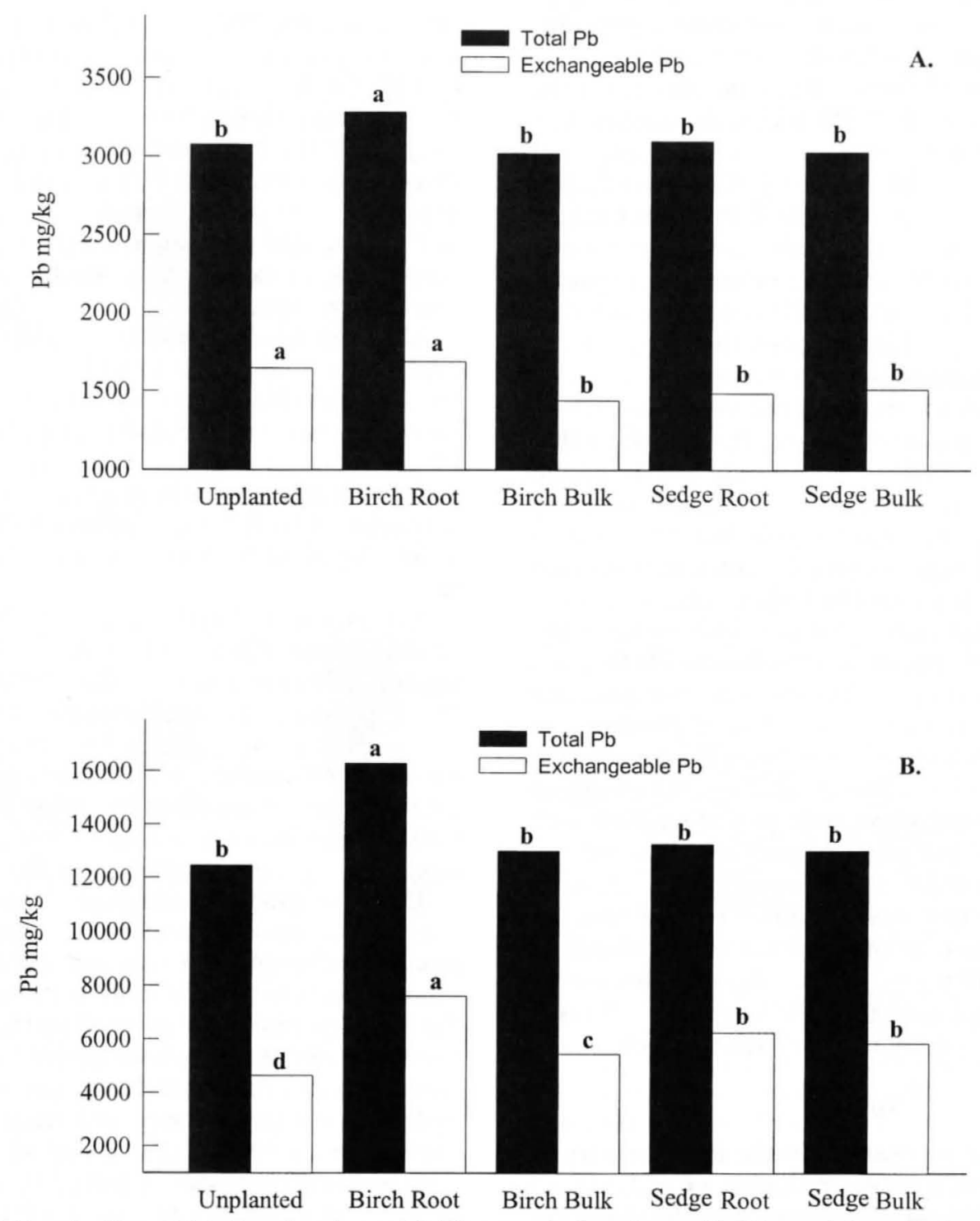

Fig. 4. Mean site soil $(A)$ and tailings $(B)$ total and exchangeable $P b$ concentrations (bars with different letters are significantly different, $D F=$ $14, p \leq 0.05$ ). (Significant tests were applied separately to the total and exchangeable $\mathrm{Pb}$ concentrations, $\mathrm{DF}=14, p \leq 0.05$ ).

LaPerche et al., 1997; Cotter-Howels and Caporn, 1996). Although not described in the literature, a similar mechanism associated with the accumulation of sulfate in the rhizosphere promoting the precipitation of $\mathrm{PbSO}_{4}$ is also plausible and also may explain the observed decreased extractability of $\mathrm{Pb}$ in the site rhizosphere soil.

LaPerche et al. (1997) suggested that plant uptake of phosphate could promote the dissolution of pyromorphite if the level of soil $\mathrm{P}$ available for plants was not in excess of that needed to immobilize $\mathrm{Pb}$. Such dissolution of pyromorphite could explain the increased leaching of $\mathrm{Pb}$ observed in the planted tailings treatments. Similarly, plant uptake of sulfate could promote the dissolution of $\mathrm{PbSO}_{4}$. The solubility of $\mathrm{PbSO}_{4}$ is $\mathrm{pH}$ independent and is inversely proportional to the soluble sulfate concentration (Lindsay, 1979).

The reason plant processes would promote the immobilization of $\mathrm{Pb}$ in the site soil and mobilization of $\mathrm{Pb}$ in the tailings may be explained by differences in soil treatment characteristics. The initial soluble $\mathrm{S}$ and available $\mathrm{P}$ concentrations measured in the site soil were much greater than in the tailings (Table 1). The same characteristics (organic and clay content) that promote a greater buffering capacity in the site soil also will contribute to its ability to retain phosphate and sulfate. Thus, plant processes would have less of an effect on the relative concentrations of phosphate and sulfate in the site soil than in the tailings.

\section{CONCLUSIONS}

The results of the laboratory study confirmed earlier field evaluations that indicated the two native species, birch and smallwing sedge, were $\mathrm{Pb}$ resistant. Significant differences in the mechanisms of $\mathrm{Pb}$ resistance displayed by the birch (excluder) and smallwing sedge (accumulator) were observed. The effect plants had on the behavior of $\mathrm{Pb}$ in soil was shown to depend on the mechanism of resistance used and was also soil specific.

As a result of the exclusionary behavior of the birch, the rhizosphere became enriched in $\mathrm{Pb}$ over time in both soil treatments. Our results suggested that the ex- 


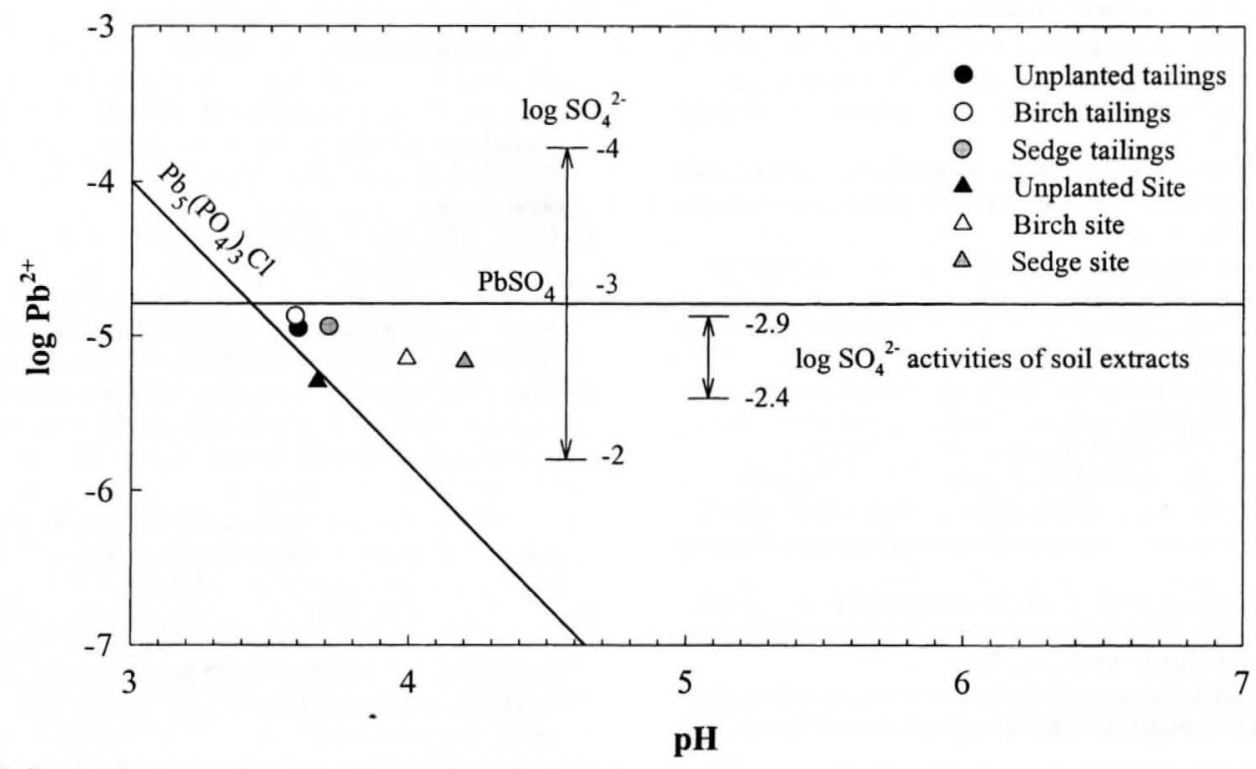

Fig. 5. Estimated $\mathrm{Pb}^{+2}$ activities for unplanted and rooting zone site soil and tailings samples based on geochemical modeling using GEOCHEMPC. [Solubility plots for solid phases are for reference only and were taken from Lindsay (1979). Lindsay (1979) explains that the P activity for the pyromorphite isotherm was fixed by strengite and soil $\mathrm{Fe}]$.

clusionary mechanism of the birch may promote soil $\mathrm{Pb}$ stabilization, as observed in the site soil, by concentrating $\mathrm{Pb}$ from the surrounding soil in the rhizosphere in a relatively less-mobile form. In contrast, a mechanism of accumulation used by smallwing sedge may promote soil $\mathrm{Pb}$ stabilization and decontamination by reducing the relative mobility of $\mathrm{Pb}$ in both the rhizosphere and adjacent soil by concentrating it in the plant. However, neither species had an effect on the leaching of $\mathrm{Pb}$ from a contaminated soil $(3000 \mathrm{mg} \mathrm{Pb} / \mathrm{kg}$ ) and both species promoted the leaching of $\mathrm{Pb}$ from highly contaminated tailings (13000 mg Pb/kg).

The increased leaching of $\mathrm{Pb}$ in the tailings was associated with a decrease in $\mathrm{pH}$. Such a reduction in $\mathrm{pH}$ was probably due to root exudation of organic acids in such a poorly buffered system. Root exudates may have promoted $\mathrm{Pb}$ solubility by increasing the concentration of organic complexing agents and $\mathrm{pH}$ adjustment, since the solubility of most mineral phases of $\mathrm{Pb}$ increases with decreasing $\mathrm{pH}$.

In addition, we provided evidence that either $\mathrm{PbSO}_{4}$ or $\mathrm{Pb}_{5}\left(\mathrm{PO}_{4}\right)_{3} \mathrm{Cl}$ is the primary mineral phase that could be controlling the solubility of $\mathrm{Pb}$ in both soil treatments. Therefore, we have proposed that plant processes affecting the levels of sulfate or phosphate in soil could explain both the immobilization and mobilization of $\mathrm{Pb}$ observed in the planted treatments. Further studies evaluating the solubility of $\mathrm{Pb}$ in the soils used are required to better understand how plants may have affected $\mathrm{Pb}$ mobility.

Clearly the use of plants to clean up or stabilize such highly contaminated soils as used in this study is not practical. However, the results of this study suggest that future studies on the effects of plant-soil interactions on the fate and mobility of $\mathrm{Pb}$ in soils would be useful for evaluating the potential of phytoremediation for the stabilization and decontamination of soils with relatively low levels of $\mathrm{Pb}$ contamination.

We recognized the need to focus on native plant spe- cies adapted to the local environment and tolerant of highly disturbed conditions typical of abandoned mine sites in the Intermountain West. This approach was successful in demonstrating the relationship between how differences in metal resistance translate into differences in both soil metal decontamination and stabilization. Such information is critical to the development of phytoremediation strategies for abandoned mine sites as well as other areas affected by heavy metal contamination.

\section{ACKNOWLEDGMENTS}

We gratefully acknowledge financial support for this project by the USGS 104 Program and the State of Utah Mineral Lease and State Appropriation Funds.

\section{REFERENCES}

Abacus Concepts. 1993. StatView 4.01. Abacus Concepts, Berkeley, CA.

Amacher, M.C., R.W. Brown, J. Kotuby-Amacher, and A. Willis. 1993. Adding sodium hydroxide to study metal removal in a stream affected by acid mine drainage. Res. Paper INT-465. USDA Forest Service Intermountain Research Station, Logan, UT.

Anderson, T.E., E.A. Gutherie, and B.T. Walton. 1993. Bioremediation in the rhizosphere. Environ. Sci. Technol. 27:2630-2636.

Baker, A.J.M., and R.R. Brooks. 1989. Terrestrial higher plants which hyperaccumulate metallic elements-A review of their distribution, ecology, and phytochemistry. Biorecovery 1:81-126.

Baker, A., R. Brooks, and R. Reeves. 1988. Growing for gold and copper and zinc. New Scientist 10:44-48.

Baker, A.J.M., R.D. Reeves, and A.S.M. Hajar. 1994. Heavy metal accumulation and tolerance in British populations of the metallophyte Thalaspi caerulescens J. \& C. Presl (Brassicaceae). New Phytol. 127:61-68.

Banks, M.K., A.P. Schwab, G.R. Fleming, and B.A. Hetrick. 1994a. Effects of plants and soil microflora on leaching of zinc from mine tailings. Chemosphere 29:1691-1699.

Banks, M.K., C.Y. Waters, and A.P. Schwab. 1994b. Influence of organic acids on leaching of heavy metals from contaminated mine tailings. J. Environ. Sci. Health 5:1045-1056.

Barnhisel, R., and P.M. Bertsch. 1982. Aluminum. p. 275-300. In A.L. Page et al. (ed.) Methods of soil analysis. Part 2. 2nd ed. Agron. Monogr. 9. ASA and SSSA, Madison, WI. 
Burken, J.G., and J.L. Schnoor. 1996. Phytoremediation: Plant uptake of atrazine and role of root exudates. J. Environ. Eng. 122:958-963.

Chaney, R., S. Brown, Y. Ming Li, J.S. Angle, F. Homer, and C. Green. 1995. Potential use of metal hyperaccumulators. Mining Environ. Manage. 9:9-11.

Cotter-Howels, J.D., and S. Caporn. 1996. Remediation of contaminated land by formation of heavy metal phosphates. Appl. Geochem. 11:335-342.

Cunningham, S.D., W.R. Berti, and J.W. Huang. 1995. Remediation of contaminated soils and sludges by green plants. p. 33-53. In R.E. Hinchee et al. (ed.) Bioremediation of inorganics. Battelle Memorial Institute, Columbus, $\mathrm{OH}$.

Donnelly, J.R., J.B. Shane, and P.G. Schaberg. 1990. Lead mobility within the xylem of red spruce seedlings: Implications for the development of pollution histories. J. Environ. Qual. 19:268-271.

Dunbabin, J.S., J. Pokorny, and K.H. Bowmer. 1988. Rhizosphere oxygenation by Typha domingensis Pers. in miniature artificial wetland filters used for metal removal from wastewaters. Aquatic Botany 7:303-317.

Gee, G.W., and J.W. Bauder. 1986. Particle size analysis. p. 383-411. In A. Klute (ed.) Methods of soil analysis. Part 1. 2nd ed. Agron. Monogr. 9. ASA and SSSA, Madison, WI.

Huang, J.W., and S.D. Cunningham. 1996. Lead phytoextraction: Species variation in lead uptake and translocation. New Phytol. 134: $1-10$.

Jones, J.B., and V.W. Case. 1990. Sampling, handling, and analyzing plant tissue samples. p. 389-427. In R.L. Westerman (ed.) Soil testing and plant analysis. 3rd ed. SSSA Book Ser. 3. SSSA, Madison, WI.

Keeney, D.R., and D.W. Nelson. 1982. Nitrogen-Inorganic forms. p. 643-698. In A.L. Page et al. (ed.) Methods of soil analysis. Part 2. 2nd ed. Agron. Monogr. 9. ASA and SSSA, Madison, WI.

Klassen, S.P. 1998. Plant species native to the Intermountain West for use in the phytoremediation of lead-contaminated soils. M.S. thesis. Utah State Univ., Logan.

Kumar, P.B.A.N., V. Dushenkov, H. Motto, and I. Raskin. 1995. Phytoextraction: The use of plants to remove heavy metals from soils. Environ. Sci. Technol. 29:1232-1238.

LaPerche, V., T.J. Logan, P.G. Daddam, and S.J. Traina. 1997. Effect of apatite amendments on plant uptake of lead from contaminated soil. Environ. Sci. Technol. 31:2745-2753.

Larcher, W. 1980. Physiological plant ecology. Springer-Verlag, Berlin.

Lepp, N.W., and G.J. Dollard. 1974. Studies on lateral movement of $\mathrm{Pb}$ in woody stems: Patterns observed in dormant and non-dormant stems. Oecologia (Berlin) 16:179-184.

Levitt, J. 1980. Responses of plants to environmental stresses. Academic Press, New York.

Lidstone, H., and S. Anderson. 1993. American Fork hydrology and water quality. Lidstone \& Anderson, Fort Collins, CO.

Lindsay, W.L. 1979. Chemical equilibria in soils. John Wiley \& Sons, New York.
Marschner, H. 1995. The soil-root interface (rhizosphere) in relation to mineral nutrition. p. 537-595. In H. Marschner (ed.) Mineral nutrition for higher plants. Academic Press, New York.

Marschner, H., and V. Romheld. 1996. Root induced changes in the availability of micronutrients in the rhizosphere. p. 557-580. In Y. Waisel et al. (ed.) Plant roots-The hidden half. Marcel Dekker, New York.

McLean, J.E., and B.E. Bledsoe. 1992. Behavior of metals in soils. EPA/540/S-92/018. USEPA, Cincinnati, $\mathrm{OH}$.

Mench, M., and E. Martin. 1991. Mobilization of cadmium and other metals from two soils by root exudates of Zea mays L., Nicotiana tabacum L., and Nicotiana rustica L. Plant Soil 132:187-196.

Nelson, D.W., and L.E. Sommers. 1982. Total carbon, organic carbon, and organic matter. p. 539-580. In A.L. Page et al. (ed.) Methods of soil analysis. Part 2. 2nd ed. Agron. Monogr. 9. ASA and SSSA, Madison, WI.

Olsen, S.R., and L.E. Sommers. 1982. Phosphorus. p. 403-430. In A.L. Page et al. (ed.) Methods of soil analysis. Part 2. 2nd ed. Agron. Monogr. 9. ASA and SSSA, Madison, WI.

Parker, D.R., W.A. Norvell, and R.L. Chaney. 1995. GEOCHEM-PC: A chemical speciation program for IBM and compatible personal computers. p. 253-269. In R.H. Loeppert et al. (ed.) Chemical equilibrium and reaction models. SSSA Spec. Publ. 42. ASA and SSSA, Madison, WI

Rhoades, J.D. 1982. Soluble salts. p. 167-180. In A.L. Page et al. (ed.) Methods of soil analysis. Part 2. 2nd ed. Agron. Monogr. 9. ASA and SSSA, Madison, WI.

Richards, L.A. (ed.) 1954. Diagnosis and improvement of saline and alkali soils. Agric. Handbook no. 60. USDA, Washington, DC

SAS Institute. 1996. Selected SAS documentation for STAT 634: Analysis of messy data. SAS Inst., Cary, NC.

Schnoor, J.L., L.A. Licht, S.C. McCutcheon, N.L. Wolfe, and L.H Carreira. 1995. Phytoremediation of organic and nutrient contaminants. Environ. Sci. Technol. 29:318-323.

Shaw, A.J. (ed.) 1990. Heavy metal tolerance in plants: Evolutionary aspects. CRC Press, Boca Raton, FL.

Sudhakar, C., L. Syamalabai, and K. Veeranjaneyulu. 1992. Lead tolerance of certain legume species grown on lead ore tailings. Agric. Ecosyst. Environ. 41:253-261.

Tessier, A., P.G.C. Campbell, and M. Bisson. 1979. Sequential extraction procedure for the speciation of particular trace metals. Anal. Chem. 51:844-850.

Traina, S.J., and V. LaPerche. 1999. Contaminant bioavailability in soils, sediments, and aquatic environments. Proc. Natl. Acad. Sci. 96:3365-3371

USEPA. 1992. SW-846 Method 3050A acid digestion of sediments, sludges, and soils. USEPA, Office of Research and Development, Washington, DC.

Wu, J., F.C. Hsu, and S.D. Cunningham. 1999. Chelate-assisted Pb phytoextraction: $\mathrm{Pb}$ availability, uptake, and translocation constraints. Environ. Sci. Technol. 33:1898-1904. 